\title{
Association of PIN3 16-bp duplication polymorphism of TP53 with breast cancer risk in Mali and a meta-analysis
}

Brehima Diakite ${ }^{*^{*}}$ D, Yaya Kassogue ${ }^{1}$, Guimogo Dolo1, Oumar Kassogue ${ }^{1}$, Mamadou Lassine Keita ${ }^{2}$, Brian Joyce ${ }^{3,4}$, Erin Neuschler, Jun Wang 3,4, Jonah Musa ${ }^{3,4,6}$, Cheick Bougari Traore ${ }^{1,2}$, Bakarou Kamate ${ }^{1,2}$, Etienne Dembele , Sellama Nadifi', Mercy Isichei ${ }^{6}$, Jane L. Holl ${ }^{8}$, Robert Murphy ${ }^{4}$, Seydou Doumbia ${ }^{1}$, Lifang Hou $^{3,4+}$ and Mamoudou Maiga ${ }^{1,3,4+}$

\begin{abstract}
Background: Breast cancer, the most common tumor in women in Mali and worldwide has been linked to several risk factors, including genetic factors, such as the PIN3 16-bp duplication polymorphism of TP53. The aim of our study was to evaluate the role of the PIN3 16-bp duplication polymorphism in the susceptibility to breast cancer in the Malian population and to perform a meta-analysis to better understand the correlation with data from other populations.

Methods: We analyzed the PIN3 16-bp duplication polymorphism in blood samples of 60 Malian women with breast cancer and 60 healthy Malian women using PCR. In addition, we performed a meta-analysis of case-control study data from international databases, including Pubmed, Harvard University Library, Genetics Medical Literature Database, Genesis Library and Web of Science. Overall, odds ratio (OR) with 95\% Cl from fixed and random effects models were determined. Inconsistency was used to assess heterogeneity between studies and publication bias was estimated using the funnel plot.

Results: In the studied Malian patients, a significant association of PIN3 16-bp duplication polymorphism with breast cancer risk was observed in dominant (A1A2 + A2A2 vs. A1A1: $O R=2.26, C l 95 \%=1.08-4.73 ; P=0.02)$ and additive (A2 vs. A1: $\mathrm{OR}=1.87, \mathrm{Cl} 95 \%=1.05-3.33 ; P=0.03)$ models, but not in the recessive model $(P=0.38)$. In the meta-analysis, nineteen (19) articles were included with a total of 6018 disease cases and 4456 controls. Except for the dominant model $(P=0.15)$, an increased risk of breast cancer was detected with the recessive $(O R=1.46,95 \%$ $\mathrm{Cl}=1.15-1.85 ; P=0.002)$ and additive $(\mathrm{OR}=1.11,95 \% \mathrm{Cl}=1.02-1.19 ; P=0.01)$ models.

Conclusion: The case-control study showed that PIN3 16-bp duplication polymorphism of TP53 is a significant risk factor for breast cancer in Malian women. These findings are supported by data from the meta-analysis carried out on different ethnic groups around the world.
\end{abstract}

Keywords: Breast cancer, TP53, PIN316-bp duplication, Meta-analysis, Malian population

\footnotetext{
* Correspondence: br.diakite@yahoo.fr

${ }^{\dagger}$ Lifang Hou and Mamoudou Maiga contributed equally to this work.

${ }^{1}$ Faculty of Medicine and Odontostomatology, University of Technical and

Technological Sciences of Bamako (USTTB), 1805, Point G, Bamako, Mali

Full list of author information is available at the end of the article
}

(c) The Author(s). 2020 Open Access This article is licensed under a Creative Commons Attribution 4.0 International License, which permits use, sharing, adaptation, distribution and reproduction in any medium or format, as long as you give appropriate credit to the original author(s) and the source, provide a link to the Creative Commons licence, and indicate if changes were made. The images or other third party material in this article are included in the article's Creative Commons licence, unless indicated otherwise in a credit line to the material. If material is not included in the article's Creative Commons licence and your intended use is not permitted by statutory regulation or exceeds the permitted use, you will need to obtain permission directly from the copyright holder. To view a copy of this licence, visit http://creativecommons.org/licenses/by/4.0/ The Creative Commons Public Domain Dedication waiver (http://creativecommons.org/publicdomain/zero/1.0/) applies to the data made available in this article, unless otherwise stated in a credit line to the data. 


\section{Background}

Breast cancer as a multifactorial disease is the most diagnosed cancer among women worldwide [1]. The incidence of breast cancer in women would be higher in developed countries due to the great heterogeneity in terms of polymorphism frequency, proportion of deletions and insertions, but with the recent improvements and availability of diagnostic infrastructure in LMICs, the detection rate has continued to increase. Over the past decade, the number of women globally affected has increased, but data from LMICs are still limited [2]. With the advent of genomics, dramatic advances have been made in breast cancer research. Recent report showed that in addition to clinical, lifestyle and environmental risk factors, an individual's genetic background plays a crucial role in the development of breast cancer [3]. Several genes have been shown to be associated with an increased risk of breast cancer, such as damaged DNA repair genes (BRCA1 and BRCA2), tumor protein p53 (TP53), Checkpoint kinase 2 (CHEK2), methylenetetrahydrofolate reductase (MTHFR), fibroblast growth factor receptor 2 (FGFR2) and glutathione S-transferase mu 1 (GSTM1) [4]. TP53, a tumor suppressor gene, is involved not only in the development of breast cancer, but also in the development of other human cancers. Indeed, this gene plays a significant role in the response to stress. The protein TP53, also called the genome guardian, is a transcription factor that controls the expression of many genes involved in cell cycle regulation, DNA repair, cell death and senescence [5-8]. The great heterogeneity reported in the TP53 in breast cancer may be linked to the geographic origin and ethnic differences of patients [8-10].

The TP53 is located on the chromosome 17p13.1 [11] and consists of 12 exons (https://www.ncbi.nlm.nih.gov/ gene/7157). It is highly polymorphic both in exonic and intronic regions with more than 200 polymorphisms (http:// www-p53.iarc.fr/). Of these, p.Arg72Pro, p.Pro47Ser and PIN3 16-bp duplication of TP53 are the most studied polymorphisms because of their critical roles in modifying the function and/or expression of TP53 [7, 12]. Sequence changes in the coding region affected by 16 bp duplication of PIN3 may result in impaired function and expression of p53 [13]. This disturbance is involved in the etiopathology of many cancers, including breast cancer $[14,15]$. Several studies around the world have found an association between the polymorphisms of this gene and the development of breast cancer $[16,17]$, while others have found no effect [18-20]. It has been reported in developed countries that individuals harboring the A2A2 genotype or 16-bp duplication in intron 3 of TP53 are at increased risk of breast cancer [21, 22]. However, very few studies have been performed in Africa populations [19], especially in Mali. The literature review revealed that the association between the
PIN3 $16 \mathrm{bp}$ duplication polymorphism and the risk of breast cancer has not been evaluated in our population. Consequently, we carried out the present work in order to understand firstly the relation between the duplication PIN3 $16 \mathrm{bp}$ and the development of breast cancer in the Malian population and secondly to carry out a comparative meta-analysis of different studies around the world to better estimate the risk of breast cancer.

The literature review showed that the relationship between PIN3 16-bp duplication polymorphism and the risk of breast cancer has not been evaluated in our population. Therefore, we carried out the present work in order to understand firstly the relation between PIN3 16-bp duplication and the risk of breast cancer in the Malian population and secondly to perform a comparative meta-analysis of different studies around the world better to estimate the risk of breast cancer.

\section{Methods \\ Case control study \\ Subject selection and sample collection}

The study was approved by the ethics committee of the Faculty of Medicine and Odontostomatology (2018/63/ CE/FMPOS) at the University of Sciences, Techniques and Technologies of Bamako (USTTB). The study was explained to each participant prior being asked to sign the approved Informed Consent.

Sixty women (mean age $43.72 \pm 3.14$ ) with clinically and histologically diagnosed breast cancer and 60 age-matched apparently healthy women (mean age $43.90 \pm 2.92$ ) from the general population were recruited at the University Hospital Center (CHU) of Point G in Bamako, Mali, between July 2018 and July 2019. All cases had early stage cancer (stage II). Clinico-pathological parameters including age at diagnosis, localization, use of contraceptive, menopausal status, parity, breastfeeding, family history of breast cancer, history of benign breast disease, obesity, smoking, histological type, tumor size, nodal involvement and metastasis were collected from each patient's medical record. In the control group, the inclusion criteria were all Malian women aged of 18 years or over coming from the general population of whom no chronic disease has ever been diagnosed (such as cancer, diabetes, etc.) and having accepted informed consent. Healthy subjects with a history of breast cancer, chronic diseases such as diabetes, or other types of cancer were excluded as controls. A total Five milliliter of peripheral blood was collected from each participant in an EDTA tube for thegenotyping analysis of PIN3 16-bp duplication polymorphism of TP53.

\section{Genotyping of PIN3 16-bp duplication}

Qiagen's GentaPuregene Extraction Kit was used to extract the genomic DNA from white blood cells. DNA quantity and quality were determined by spectrophotometer. 
Genotyping of PIN316-bp duplication polymorphism was performed by allele specific PCR (AS-PCR) using published primers previously described $[17,19,23,24]$. A final reaction volume of $25 \mu \mathrm{l}$ containing $12.8 \mu \mathrm{l}$ buffer, $1.5 \mu \mathrm{l} \mathrm{MgCl} 2$, $1.5 \mu \mathrm{l}$ dNTPs, $1.0 \mu \mathrm{l}$ primers, $2.0 \mu \mathrm{l}$ Taq DNA polymerase, and $2.0 \mu \mathrm{l}$ genomic DNA was used to amplify the PIN3 16bp duplication of the TP53. PCR amplification conditions were previously described by Maarouf and al [19].. The PCR products after electrophoresis on a $4.5 \%$ agarose gel showed a fragment of $119 \mathrm{bp}$ for the A1 allele (wild type or no duplication) and a fragment of $135 \mathrm{bp}$ for the A2 allele (Insert or 16-bp duplication).

\section{Statistical analysis}

SPSS 11.0 was used to analyze the data. Chi-square tests (two-sided) were performed to evaluate the correlation between the PIN3 16-bp duplication and the clinical and histological features. Hardy-Weinberg equilibrium for the PIN3 16-bp duplication genotype distribution of TP53 was tested by Chi2 analysis with exact probability. An odds ratio (OR) test with $95 \%$ confidence interval (CI) and $\mathrm{P}<0.05$ was used to determine the association between PIN3 16-bp duplication polymorphism of TP53 and the risk of breast cancer, according to the different genetic models (dominant: A1A2 + A2A2 vs. A1A1, recessive: $\mathrm{A} 2 \mathrm{~A} 2$ vs. $\mathrm{A} 1 \mathrm{~A} 2$ + $\mathrm{A} 1 \mathrm{~A} 1$ and additive: $\mathrm{A} 2$ vs. $\mathrm{A} 1$ ). The $P$ value $<0.05$ was considered significant.

\section{Meta-analysis study}

\section{Literature search}

The keywords "TP53", "Intron 3 Ins16 bp or PIN3 16-bp duplication"; "Polymorphism or mutation or genes" and "breast cancer" were used to perform a literature search of Pubmed, Harvard University Library, Genetics Medical Literature Database, Genesis Library and Web of Science. Only articles published in English were retained. Additional articles were identified by examining the references cited in articles and reviews retained from the search.

\section{Article inclusion criteria}

The criteria for selecting the articles were as follows: (1) Results reported about a case-control study, study published as an original study evaluating the association between PIN3 16-bp duplication polymorphism of TP53 and the risk of breast cancer; (2) No deviation from Hardy-Weinberg Equilibrium (HWE) in controls; (3) No influence on the pooled odds ratio (OR) and $p$-values (Fig. 1); and (4) Full text available. Two investigators independently reviewed the abstracts of the initial search and assessed each article for inclusion in the metaanalysis.

\section{Data extraction}

The following data were extracted from all eligible studies: first author's name, year of publication, study population,

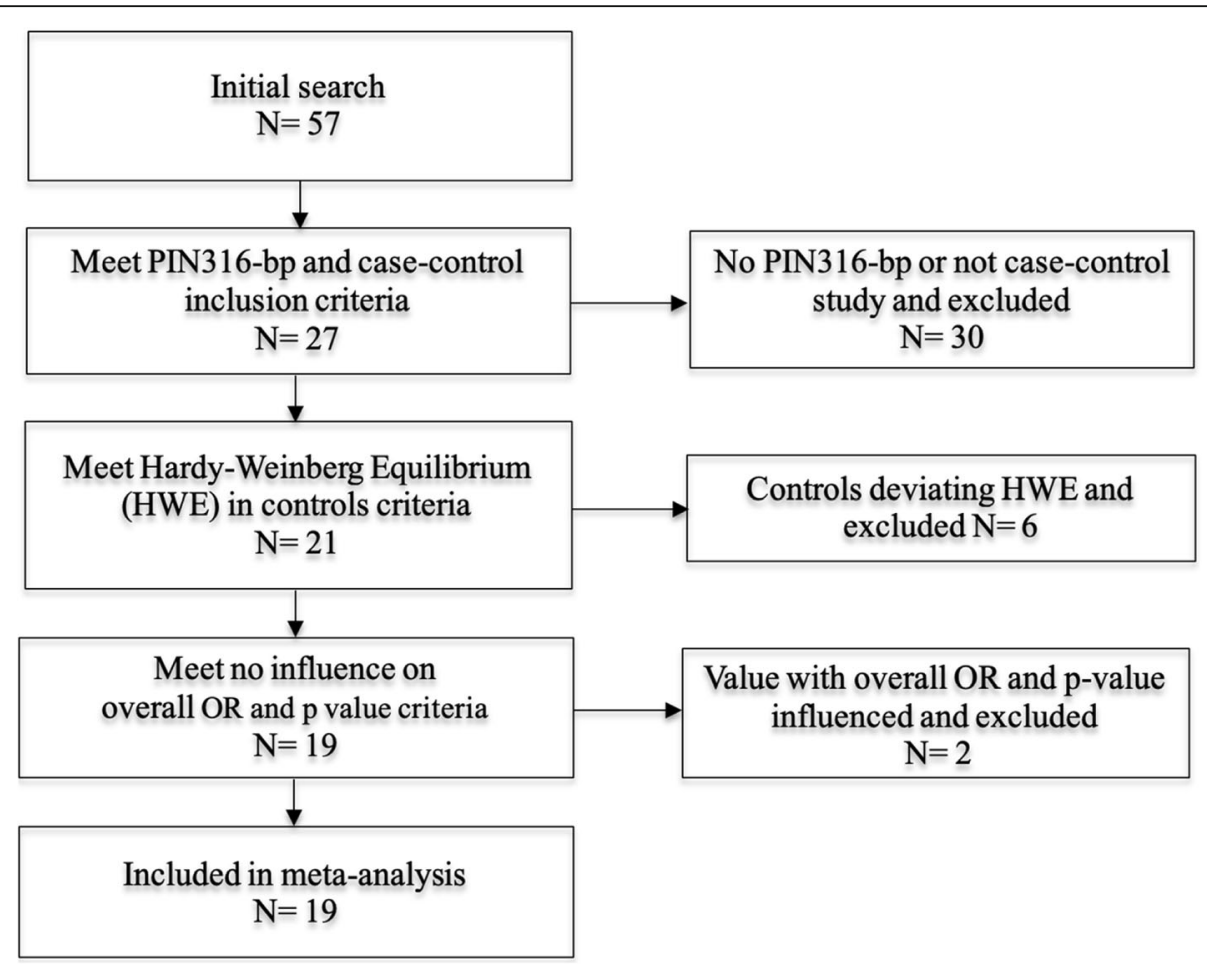

Fig. 1 Flow chart of meta-analysis for exclusion/inclusion of studies 
Table 1 Distribution of the PIN3 16-bp duplication polymorphism of TP53 according to the clinicopathological characteristics in Malian breast cancer

\begin{tabular}{|c|c|c|c|c|c|c|}
\hline \multirow[t]{2}{*}{ Clinical parameter } & \multirow[t]{2}{*}{$N(\%)$} & \multicolumn{3}{|c|}{ PIN3 16-bp duplication } & \multirow[t]{2}{*}{$x^{2}$} & \multirow[t]{2}{*}{$P$ value } \\
\hline & & $\mathrm{A} 1 \mathrm{~A} 1 \%$ & $\mathrm{~A} 1 \mathrm{~A} 2 \%$ & $\mathrm{~A} 2 \mathrm{~A} 2 \%$ & & \\
\hline Mean age at diagnosis & $43.72 \pm 3.14$ & & & & $2.41^{*}$ & 0.12 \\
\hline$\leq 40$ years of age & $29(48.3)$ & $11(37.9)$ & $12(41.4)$ & $6(20.7)$ & & \\
\hline$>40$ years of age & $31(51.7)$ & $16(51.6)$ & $13(41.4)$ & $2(6.5)$ & & \\
\hline Localization & & & & & 1.98 & 0.74 \\
\hline Right breast & $19(31.7)$ & $7(36.8)$ & $9(47.4)$ & $3(15.8)$ & & \\
\hline Left breast & $37(61.7)$ & $19(51.4)$ & $14(37.8)$ & $4(10.8)$ & & \\
\hline Bilateral & $4(6.6)$ & $1(25.0)$ & $2(50.0)$ & $1(25.0)$ & & \\
\hline Use of contraceptives & & & & & $0.56^{*}$ & 0.45 \\
\hline No & $45(75.0)$ & $18(40.0)$ & $25(55,6)$ & $2(4.4)$ & & \\
\hline Yes & $15(25.0)$ & $9(60.0)$ & - & $6(40.0)$ & & \\
\hline Menopausal status & & & & & 3.15 & 0.53 \\
\hline Pre-menopausal & $11(18.3)$ & $6(54.5)$ & $4(36.4)$ & $1(9.1)$ & & \\
\hline Post-menopausal & $20(33.3)$ & $10(50.0)$ & $9(45.0)$ & $1(5.0)$ & & \\
\hline Fertile women & $29(48.3)$ & $11(37.9)$ & $12(41.4)$ & $6(20.7)$ & & \\
\hline Parity & & & & & 7.33 & 0.12 \\
\hline Nulliparity & $6(10.0)$ & - & $5(83.3)$ & $1(16.7)$ & & \\
\hline Primiparity & $9(15.0)$ & $3(33.3)$ & $4(44.4)$ & $2(22.2)$ & & \\
\hline Multiparity & $45(75.5)$ & $24(53.3)$ & $16(35.6)$ & $5(11.1)$ & & \\
\hline Breastfeeding & & & & & $0.50^{*}$ & 0.48 \\
\hline Yes & $53(88.3)$ & $26(49.1)$ & 19 (35.8) & $8(15.1)$ & & \\
\hline No & $7(11.7)$ & $1(14.3)$ & $6(85.7)$ & - & & \\
\hline Family history of $\mathrm{BC}$ & & & & & $0.64^{*}$ & 0.42 \\
\hline Yes & $8(13.3)$ & $4(50.0)$ & $4(50.0)$ & - & & \\
\hline No & $52(86.7)$ & $23(44.2)$ & $21(40.4)$ & $8(15.4)$ & & \\
\hline Personal history of benign breast disease & & & & & $1.69^{*}$ & 0.19 \\
\hline Yes & $6(10.0)$ & $4(66.7)$ & $2(33.3)$ & - & & \\
\hline No & $54(90.0)$ & $23(42.6)$ & $23(42.6)$ & $8(14.8)$ & & \\
\hline Obesity & & & & & 0.43 & 0.81 \\
\hline Yes & $19(31.7)$ & $8(42.1)$ & $9(47.4)$ & $2(10.5)$ & & \\
\hline No & $41(68.3)$ & $19(46.3)$ & $16(39.0)$ & $6(14.6)$ & & \\
\hline Smoking & & & & & $0.20^{*}$ & 0.65 \\
\hline Passive smoking & $7(11.7)$ & $3(42.9)$ & $4(57.1)$ & - & & \\
\hline No & $53(88.3)$ & $24(45.3)$ & 21 (39.6) & $8(15.1)$ & & \\
\hline Histological type & & & & & $4.14^{*}$ & 0.04 \\
\hline Invasive ductal carcinoma & $56(93.3)$ & $23(41.1)$ & $25(44.6)$ & $8(14.3)$ & & \\
\hline Others & $4(6.7)$ & $4(100.0)$ & - & - & & \\
\hline Tumor size & & & & & 5.63 & 0.46 \\
\hline $\mathrm{T} 1$ & $1(1.7)$ & - & $1(100.0)$ & - & & \\
\hline $\mathrm{T} 2$ & $10(16.7)$ & $5(50.0)$ & $5(50.0)$ & - & & \\
\hline T3 & $41(68.3)$ & $18(43.9)$ & 15 (36.6) & $8(19.5)$ & & \\
\hline T4 & $8(13.3)$ & $4(50.0)$ & $4(50.0)$ & - & & \\
\hline
\end{tabular}


Table 1 Distribution of the PIN3 16-bp duplication polymorphism of TP53 according to the clinicopathological characteristics in Malian breast cancer (Continued)

\begin{tabular}{|c|c|c|c|c|c|c|}
\hline \multirow[t]{2}{*}{ Clinical parameter } & \multirow[t]{2}{*}{$N(\%)$} & \multicolumn{3}{|c|}{ PIN3 16-bp duplication } & \multirow[t]{2}{*}{$x^{2}$} & \multirow[t]{2}{*}{$P$ value } \\
\hline & & $\overline{\mathrm{A} 1 \mathrm{~A} 1 \%}$ & $\mathrm{~A} 1 \mathrm{~A} 2 \%$ & $\mathrm{~A} 2 \mathrm{~A} 2 \%$ & & \\
\hline \multicolumn{7}{|c|}{ Nodal involvement } \\
\hline No & $36(60.0)$ & $16(44.4)$ & $16(44.4)$ & $4(11.1)$ & \multirow[t]{4}{*}{6.05} & \multirow[t]{4}{*}{0.41} \\
\hline N1 & $16(26.7)$ & $5(31.3)$ & $7(43.8)$ & $4(25.0)$ & & \\
\hline N2 & $7(11.7)$ & $5(71.4)$ & $2(28.6)$ & - & & \\
\hline N3 & $1(1.7)$ & $1(100.0)$ & - & - & & \\
\hline \multicolumn{2}{|l|}{ Metastasis } & & & & \multirow[t]{3}{*}{$0.91^{*}$} & \multirow[t]{3}{*}{0.34} \\
\hline MO & $55(91.7)$ & $24(43.6)$ & $23(41.8)$ & $8(14.5)$ & & \\
\hline $\mathrm{M} 1$ & $5(8.3)$ & $3(60.0)$ & $2(40.0)$ & - & & \\
\hline
\end{tabular}

$X^{2}$ Chi-squared test, $P p$-value, ${ }^{*}$ Chi-squared test two-sided, $N$ Number, $B C$ Breast cancer, $A 1 A 1$ Wild-type, $A 1 A 2$ heterozygous, $A 2 A 2$ homozygous mutant, $\%$ Percentagwe, Other histological type: Glycogen-rich clear cell carcinoma, lobular carcinoma in situ, Moderately differentiated adenocarcinoma and infiltrating adenocarcinoma.

sample size, genotypic and allelic distribution by two independent investigators (add the initials of the two extractors). These data were compared to find a consensus. A third investigator resolved any conflict.

\section{Statistical analysis}

Review Manager Software was used to analyze the data. The Chi-squared test with the value of $P<0.05$ was carried out to evaluate the Hardy-Weinberg equilibrium in the controls. The association of PIN3 16-bp duplication polymorphism with the risk of breast cancer in the dominant, recessive and additive models was measured by ORs with $95 \% \mathrm{CI}$. An inconsistency $\left(\mathrm{I}^{2}\right)$ test was performed to detect heterogeneity [25]. If $\mathrm{I}^{2}<50 \%$ (absence of heterogeneity), the fixed effect model (FEM) was chosen as a pooling method; otherwise, if $\mathrm{I}^{2}>50 \%$ (presence of heterogeneity), the random effect model (REM) was maintained. The addition and/or deletion of any study that modifies the value of the pooled $\mathrm{OR} \pm 1$ was done to assess the sensitivity of the meta-analysis. The funnel curve was used to identify the publication bias.

Table 2 Association of genetic models of PIN3 16-bp duplication polymorphism of TP53 with breast cancer risk

\begin{tabular}{lllll}
\hline $\begin{array}{l}\text { Genotype/ } \\
\text { Allele }\end{array}$ & Cases & Controls & OR $(95 \% \mathrm{Cl})$ & $P$ \\
\hline A1A1 & $\mathrm{N}=60$ & $\mathrm{~N}=60$ & & \\
A1A2 & $27(45.0)$ & $39(65.0)$ & Reference & \\
A2A2 & $25(41.7)$ & $16(26.7)$ & $2.25(1.01-5.01)$ & 0.04 \\
A2A2 + A1A2 & $33(55.0)$ & $21(35.0)$ & $2.26(1.08-4.73)$ & 0.02 \\
A1A1 + A1A2 & $52(86.7)$ & $55(91.7)$ & Reference & \\
A2A2 & $8(13.3)$ & $5(8.3)$ & $1.69(0.52-5.50)$ & 0.38 \\
A1 & $79(65.8)$ & $94(78.3)$ & Reference & \\
A2 & $41(34.2)$ & $26(21.7)$ & $1.87(1.05-3.33)$ & 0.03 \\
\hline
\end{tabular}

$N$ Number, $\mathrm{Cl}$ confidence Interval, $P$-value, $\mathrm{A} 2 \mathrm{~A} 2+\mathrm{A} 1 \mathrm{~A} 2$ vs. A1A1: Dominant model, $A 2 A 2$ vs. $A 1 A 1+A 1 A 2$ : Recessive model; $A 2$ vs. A1: Additive model.

\section{Results}

\section{Case control study}

We evaluated the association between PIN3 16-bp duplication polymorphism of TP53 and the risk of breast cancer in Malian women. The demographic, clinical, and pathological characteristics of the patients are shown in Table 1. The mean age of cases and controls was $43.72 \pm 3.14$ and $43.90 \pm 2.92$ years, respectively. Most of the patients had cancer in the left breast. Multiparity was reported in $75.5 \%$ of cases, breastfeeding in $88.3 \%$, no family history of breast cancer in $86.6 \%$, no history of benign breast disease in $90.0 \%$, absence of obesity in $68.3 \%$ and no history of smoking in $88.3 \%$ of the cases. Invasive ductal carcinoma forms were more prevalent than any others histological form of breast cancer (Table 1). Patients with PIN3 16-bp duplication (A2A2) of TP53 were more likely to have an invasive ductal carcinoma form, T3 stage tumor size, node involvement (N0 and N1), and M0 metastasis status compared to patients with the A1A1 or A1A2 genotype. We found no correlation between the PIN3 16-bp duplication polymorphism and the clinical features of participants except histological type $(p=0.04)$.

\section{PIN3 16-bp duplication polymorphism of TP53 and breast Cancer risk}

Table 2 shows the distribution of PIN3 16-bp duplication polymorphism of the TP53 in the cases according to the genetic models. The genotypic distribution PIN3 16-bp duplication polymorphism did not deviate from the Hardy-Weinberg equilibrium both in the cases $\left(\mathrm{X}^{2}=0.33, p=0.57\right)$ and in the controls $\left(\mathrm{X}^{2}=2.76, p=\right.$ $0.10)$. The heterozygous genotype (A1A2) was associated with an increased risk of breast cancer with $(\mathrm{OR}=2.25$, 95\% $\mathrm{CI}=1.01-5.01$ and $p=0.04)$. When we extended the analysis to the different genetic models, we noted that the dominant model $(\mathrm{A} 1 \mathrm{~A} 2+\mathrm{A} 2 \mathrm{~A} 2$ vs. A1A1: OR = 
Table 3 Summary of studies included in meta-analysis

\begin{tabular}{|c|c|c|c|c|c|c|c|c|c|c|}
\hline \multirow[t]{2}{*}{ Reference } & \multirow[t]{2}{*}{ Population } & \multicolumn{4}{|l|}{ Cases } & \multicolumn{5}{|c|}{ Controls } \\
\hline & & N & $\mathrm{A} 1 \mathrm{~A} 1$ & $\mathrm{~A} 1 \mathrm{~A} 2$ & $\mathrm{~A} 2 \mathrm{~A} 2$ & N & $\mathrm{A} 1 \mathrm{~A} 1$ & $\mathrm{~A} 1 \mathrm{~A} 2$ & $\mathrm{~A} 2 \mathrm{~A} 2$ & HWE \\
\hline Present study & Mali & 60 & 27 & 25 & 8 & 60 & 39 & 16 & 5 & 0.10 \\
\hline Akkiprik et al. 2009 [18] & Turkey & 97 & 59 & 35 & 3 & 107 & 61 & 43 & 3 & 0.15 \\
\hline Buyru et al. 2007 [26] & Turkey & 115 & 83 & 28 & 4 & 63 & 47 & 15 & 1 & 0.87 \\
\hline Cherdyntseva et al. 2012 [27] & Russia & 296 & 227 & 68 & 1 & 196 & 145 & 50 & 1 & 0.13 \\
\hline Costa et al. 2008 [17] & Portugal & 191 & 122 & 56 & 13 & 216 & 147 & 65 & 4 & 0.29 \\
\hline De Vecchi et al. 2008 [28] & Italy & 350 & 233 & 103 & 14 & 352 & 256 & 87 & 9 & 0.62 \\
\hline Gaudet et al. 2007 [29] & USA (M) & 578 & 404 & 157 & 17 & 390 & 272 & 108 & 10 & 0.85 \\
\hline Gohari-Lasaki et al. 2015 [23] & Iran & 100 & 53 & 38 & 9 & 100 & 60 & 37 & 3 & 0.34 \\
\hline Guleria et al. 2012 [30] & India & 80 & 43 & 30 & 7 & 80 & 53 & 25 & 2 & 0.64 \\
\hline Hao et al. 2018 [31] & Chine & 254 & 230 & 24 & 0 & 252 & 227 & 25 & 0 & 0.41 \\
\hline Hrstka et al. 2009 [32] & Island & 117 & 81 & 32 & 4 & 108 & 81 & 24 & 3 & 0.46 \\
\hline Morten et al. 2019 [20] & Australia & 1304 & 986 & 289 & 29 & 436 & 325 & 104 & 7 & 0.67 \\
\hline Pouladi et al. 2014 [33] & Iran & 221 & 135 & 69 & 17 & 170 & 107 & 51 & 12 & 0.10 \\
\hline Sharma et al. 2014 [7] & India & 200 & 134 & 52 & 14 & 200 & 137 & 55 & 8 & 0.41 \\
\hline Suspitsin et al. 2003 [34] & Russia & 529 & 408 & 108 & 13 & 249 & 187 & 56 & 6 & 0.47 \\
\hline Trifa et al. 2010 [35] & Tunisia & 159 & 98 & 56 & 5 & 132 & 86 & 41 & 5 & 0.97 \\
\hline Vymetalkova et al. 2015 [36] & Czech & 705 & 474 & 164 & 24 & 611 & 421 & 172 & 18 & 0.93 \\
\hline Wang-Gohrke et al. 2002 [16] & Germany & 563 & 370 & 173 & 20 & 549 & 391 & 145 & 13 & 0.92 \\
\hline Weston et al. 1997 [37] & USA (M) & 99 & 60 & 36 & 3 & 185 & 127 & 54 & 4 & 0.52 \\
\hline
\end{tabular}

$M$ Mixed, $N$ Number

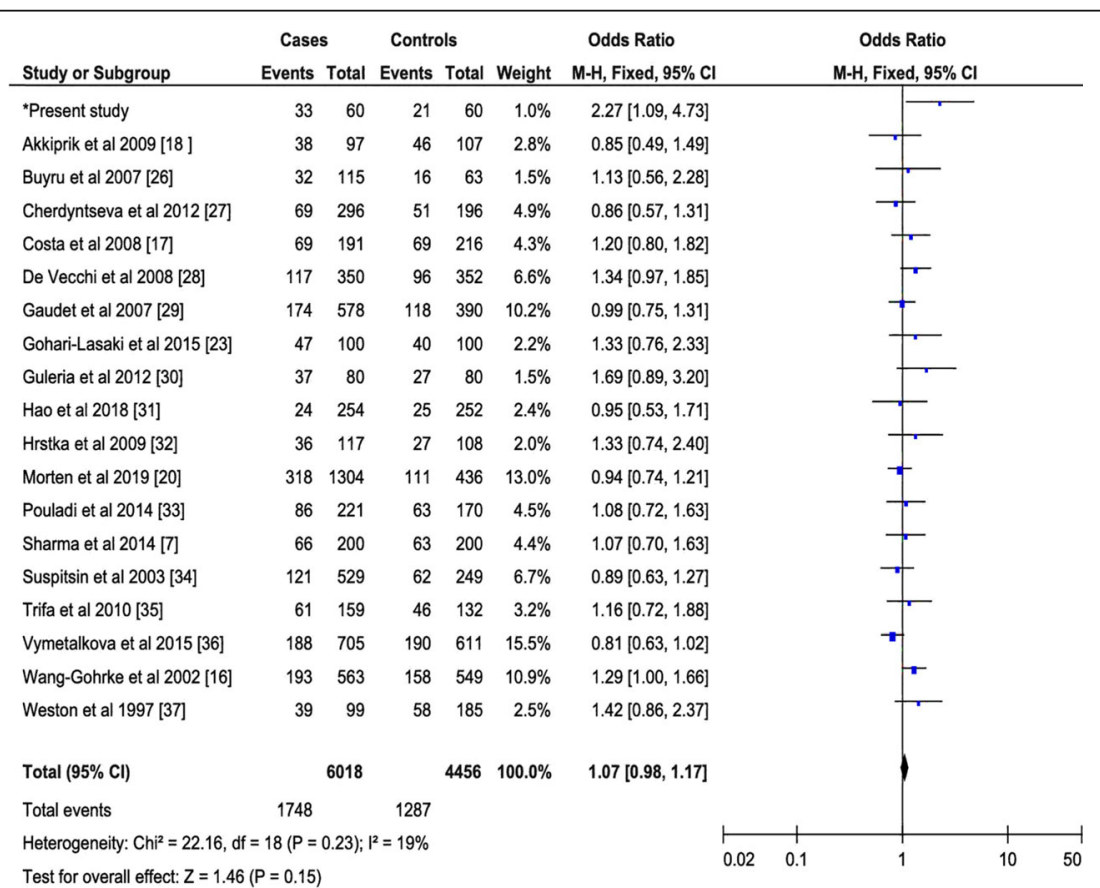

Fig. 2 Forest plots of the relationship between PIN3 16-bp duplication polymorphism of the TP53 and breast cancer in the dominant model. The black diamond denotes the pooled OR; black squares indicate the OR in each study with square sizes inversely proportional to the standard error of the OR; and horizontal lines represent the $95 \% \mathrm{Cl}$ 


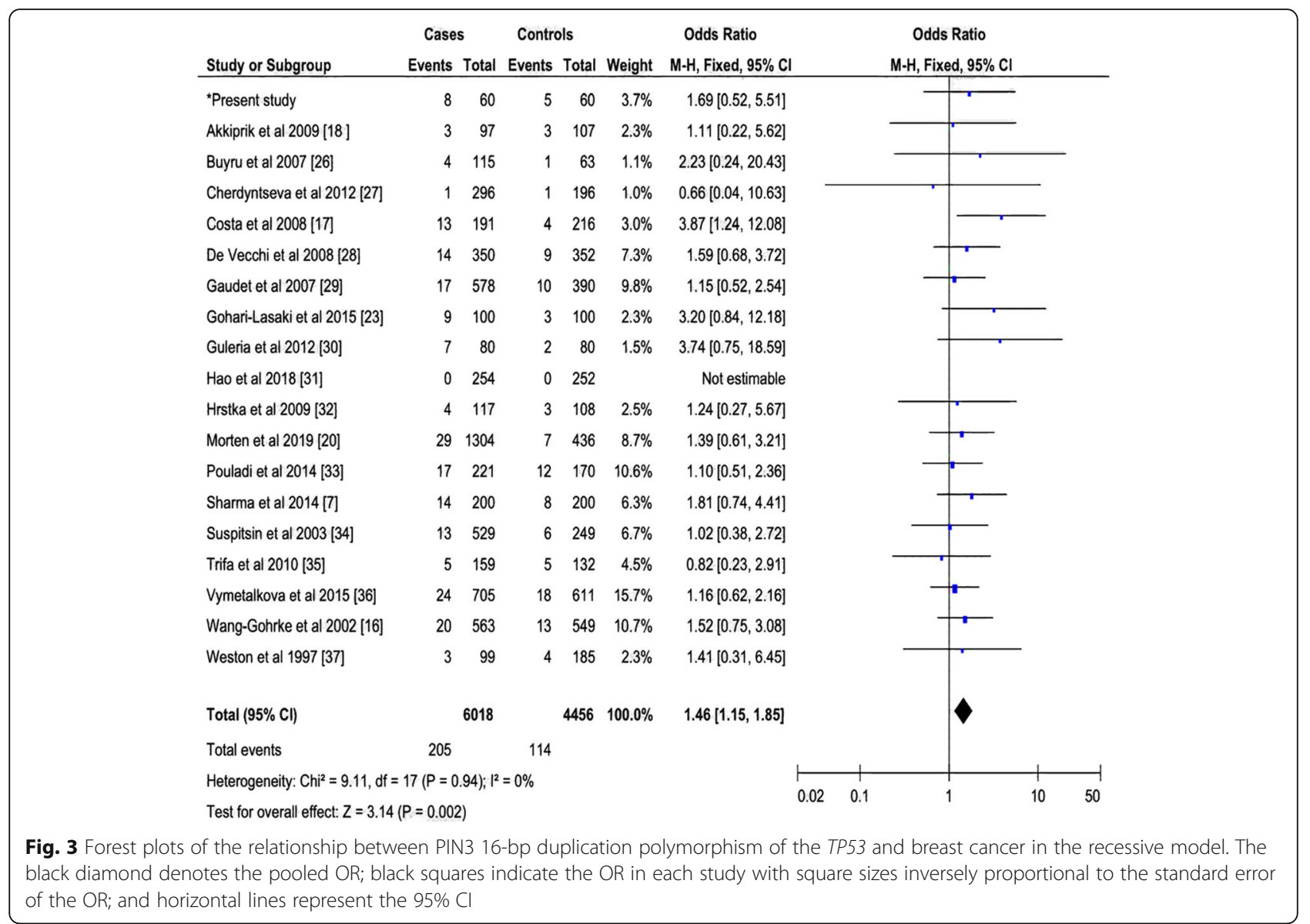

2.26, 95\% CI $=1.08-4.73, p=0.02)$ and the additive model (A2 vs $\mathrm{A} 1: \mathrm{OR}=1.87,95 \% \mathrm{CI}=1.05-3.33, p=0.03$ ) of PIN3 16-bp duplication polymorphism was significantly associated with the risk of breast cancer (Table 2).

\section{Meta-analysis study}

\section{Characteristics of included studies}

A total of 19 articles reporting case-control studies that investigated PIN3 16-bp duplication polymorphism and breast cancer risk and meeting the inclusion criteria were selected to perform the meta-analysis (Table 3, Additional file 1). Thirty studies that have not addressed PIN3 16-bp duplication of TP53, 6 studies deviating from HWE, as well as 2 studies [38, 39] which influenced the OR and $p$ values pooled were excluded (Fig. 1).

\section{Quantitative analysis}

This meta-analysis showed a significant association between PIN3 16-bp duplication polymorphism and breast cancer risk in recessive (Fixed effect model (FEM): OR = 1.46, 95\% CI $=1.15-1.85 ; p=0.002$ ) and additive (FEM: $\mathrm{OR}=1.11,95 \% \mathrm{CI}=1.02-1.19 ; p=0.01)$ models, but not in the dominant model (FEM: OR $=1.07,95 \% \mathrm{CI}=0.98-$
1.17; $p=0.15$ ). Figures 2,3 , and 4 , show the forest plots of OR for breast cancer in the dominant, recessive and additive models of PIN3 16-bp duplication polymorphism of the TP53, respectively. Figure 2.

\section{Sensitivity analysis}

The stability of the results was assessed by a sensitivity analysis. We have noted a significant association between the PIN3 16-bp duplication polymorphism and the risk of breast cancer in the recessive (Fig. 3) and additive (Fig. 4) models, except the dominant model (Fig. 2), Furthermore, the one by one elimination of eligible studies did not influence the values of the pooled OR effect in the different genetic models.

\section{Sources of heterogeneity}

After the non-inclusion of articles with HWE-deviation in controls, we noted a lack of heterogeneity in the dominant $\left(\mathbf{I}^{\mathbf{2}}=19 \%, P=0.23\right)$, recessive $\left(\mathbf{I}^{\mathbf{2}}=0 \%, P=0.94\right)$ and additive $\left(\mathbf{I}^{\mathbf{2}}=11 \%, P=0.32\right)$ models between PIN3 16-bp duplication polymorphism and breast cancer risk (Figs. 2, 3, and 4). 


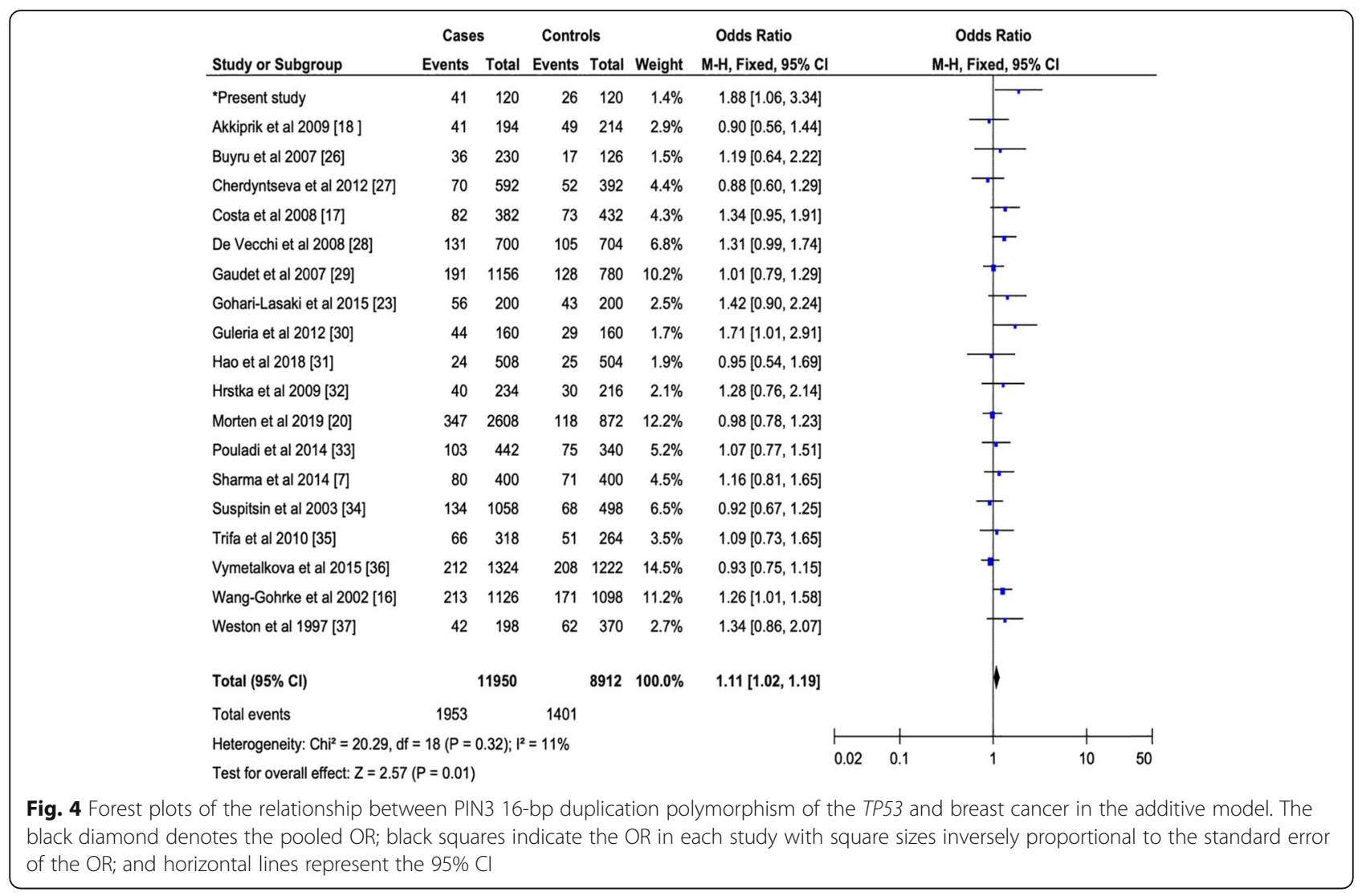

\section{Publication Bias}

A funnel plot was used to assess publication bias. After the elimination of studies that did not meet the inclusion criteria followed by the sensitivity analysis, no publication bias was observed in the recessive and additive models. However, a slight asymmetry was detected in the dominant model (Fig. 5).

\section{Discussion}

$\mathrm{n}$ the present study, we noted a positive correlation of the PIN3 16-bp duplication polymorphism of TP53 with the histological type of breast cancer. Similar results have been found in the Iranian population by Faghani et al. who reported a correlation between invasive ductal breast cancer and the PIN3 duplication polymorphism at $16 \mathrm{bp}$ [40]. Contrary to our observations, studies carried out in the Moroccan, Croatian and Czech populations have not found any link between histological types and mutations in this gene $[19,32,38]$. These contradictory results may be explained by the ethnic and geographic origin.

Our results show that the PIN3 16-bp duplication polymorphism is significantly linked to the breast cancer risk in the Malian population.

We found that heterozygous, dominant and A1A2 additive models were significantly associated with an increased risk of breast cancer. However, the results of various studies regarding the association between the
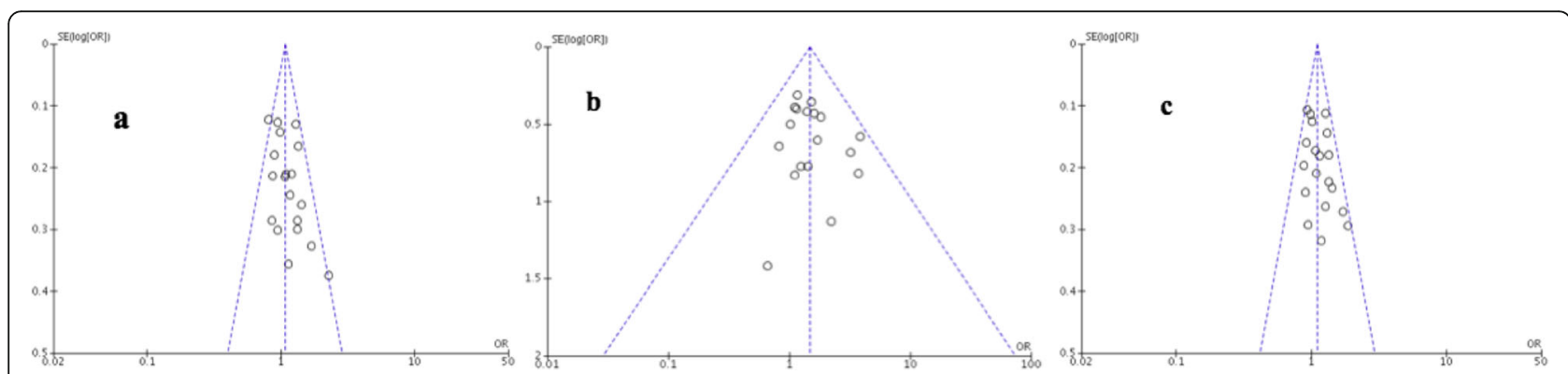

Fig. 5 Funnel plots of a dominant, $\mathbf{b}$ recessive and $\mathbf{c}$ additive models precision by OR 
PIN3 16-bp duplication of TP53 and the risk of breast cancer are contradictory. Similar to our results, Faghani et al. and $\mathrm{Wu}$ et al. reported that the A1A2 genotype is associated with the risk of breast cancer $[40,41]$ On the other hand, others studies have found no association between this genotype and the risk of breast cancer [18, $38,39]$. However, we noted that the A2A2 genotype was not associated with the development of breast cancer in our population. This observation was similar to those previously reported by in Morocco [19], in Iran [40], and Poland [42] but contradictory with the result obtained in Portugal [17]. In addition, we noted that the A2 allele was associated with the risk of breast cancer, which was consistent with the results of many authors $[30,40]$ but different from the results reported by others [31, 36]. The differences between studies may be explained by several factors such as sample size, race, ethnic differences, genetic background, environmental factors and heterogeity between the studies.

The meta-analysis, which included 6018 breast cancer patients and 4456 controls revealed an increased-risk of breast cancer with the recessive and additive models of PIN3 16-bp duplication. Two previous meta-analyzes, one covering 19 studies with 4479 cases and 4683 controls [41] and the other covering 9 studies with 2715 cases and 2595 controls [21] showed that the recessive model was associated with the risk of breast cancer. However, another meta-analysis of 6 studies with 2018 cases and 1748 controls revealed an inverse association [22], but the number of studies included and the sample size for this study were relatively small. Compared to our results, all these meta-analyzes found a significant genetic association between the additive model and breast cancer [21, 22, 41]. The mechanism associating A2 with breast cancer is not yet fully established, certain factors have been discussed. There is some evidence linking A2 status of differential expression of different p53 isoforms in lymphoblastoid cell lines, thereby causing alteration in mRNA [13, 43, 44]. Indeed, the influence of A2 allele on the alternative splicing of p53 protein causes an instability of the transcripts or proteins with modified functions. Many investigators have reported the existence of linkage disequilibrium between 6-bp duplication and other variants of TP53 such as codon 72 or p.Arg72Pro, intron $6[31,45]$. The codon $72 \mathrm{Arg} / \mathrm{Pro}$, intron 3 16-bp duplication and intron $6 \mathrm{G}>$ A TP53 haplotype was associated with the ability to repair DNA in lymphoblastic cell lines and apoptic reduction $[21,46]$. Thus, the polymorphisms of TP53 could affect the activity of $p 53$ by triggering the process of carcinogenesis.

This study has some limitations such as small sample size, lack of hormonal receptors tests and subgroup analyzes in the meta-analysis. Another limitation is the collection of data limited to the demographic parameters and history of the disease in controls.

\section{Conclusions}

The present study made it possible to establish for the first time the distribution of alleles and genotypes of PIN3 16bp duplication polymorphism of TP53 in the Malian population and to understand the relationship between this gene and the risk of breast cancer. Our results have shown that this polymorphism is not only associated with the histological type, but also is with the risk of breast cancer in Malian population. In addition, the meta-analysis carried out confirmed our findings.

\section{Supplementary information}

Supplementary information accompanies this paper at https://doi.org/10. 1186/s12881-020-01072-4.

Additional file 1. Availability of all data and references with PubMed accession numbers

\section{Abbreviations}

AS-PCR: Allele Specific PCR; CHU : University Hospital Center; Cl : Confidence Interval; FEM : Fixed effect model; HWE: Hardy-Weinberg Equilibrium; LMICs: Low- and middle-income countries; OR : Odd ratio; REM : Random effect model; USTTB : University of Science, Technique, and Technologies at Bamako

\section{Acknowledgements \\ The authors thank all participants in the study; the Faculty of Medicine and Odontostomatology of the University of Sciences, Techniques, and Technologies at Bamako, the University Clinical Research Center (UCRC-Mali), Intelligence Center of Excellence Mali (ICER-Mali); Cheick Fantamady Traore, Prof. Mamadou Diakite and Dr. Mamadou Coulibaly for logistical support. They also thank Harvard University, Boston University, Northwestern University, and University of New Mexico (HBNU) Consortium, Global Health, Fogarty International Center and the National Institutes of Health for their training support.}

\section{Authors' contributions}

All authors read and approved the final manuscript. Study concept and design: BD, YK, OK, JW, EN, GD, ED, SN, SD, LH, MM. Clinical data collection: MLK, CBT, BK. Acquisition of genetic data: BD, YK, OK. Analysis and interpretation of data: BD, YK, OK, MM, MLK, JW, JM, EN $B J, C B T, G D, B K, E D, S N, M I, J L H, R M, S D, L H$. Drafting of the manuscript: BD with assistance from by BD, YK, OK, MM, MLK, JW, JM, EN, BJ, CBT, GD, BK, ED, SN, MI, JLH, RM, SD, LH. Critical revision of the manuscript for important intellectual content: BD, YK, OK, MM, MLK, JW, JM, EN, BJ, CBT, GD, BK, ED, SN, MI, JLH, RM, SD, LH. Obtaining supervision: MM, LH, RM.

\section{Funding}

Research reported in this publication was supported by the HBNU Consortium, Fogarty International Center and the National Institutes of Health under Award Number D43 TW010543. The content is solely the responsibility of the authors and does not necessarily represent the official views of the National Institutes of Health.

\section{Availability of data and materials}

The datasets generated and/or analyzed in the Malian population study are available from the corresponding author upon reasonable request and with the permission of FMPOS Ethics Committee. The meta-analysis dataset analyzed is available in the additional file 1. 


\section{Ethics approval and consent to participate}

This study was approved by the FMPOS Ethics Committee (IRB N ${ }^{\circ}$ 2018/63/ (E/FMPOS), Université des Sciences, des Techniques et des Technologies de Bamako (USTTB), Mali. All participants accepted and signed the written informed consent.

\section{Consent for publication}

Not applicable.

\section{Competing interests}

The authors declare that they have no competing interests.

\section{Author details}

${ }^{1}$ Faculty of Medicine and Odontostomatology, University of Technical and Technological Sciences of Bamako (USTTB), 1805, Point G, Bamako, Mali. ${ }^{2}$ University Teaching Hospital Point G, Bamako, Mali. ${ }^{3}$ Preventive Medicine Department, Cancer Epidemiology and Prevention, Northwestern University, Chicago, IL 60611, USA. ${ }^{4}$ Institute for Global Health, Northwestern University, Chicago, IL 60611, USA. ${ }^{5}$ Department of Radiology, College of Medicine, University of Illinois at Chicago, Chicago, IL 60612, USA. ${ }^{6}$ Department of Obstetrics and Gynecology, Faculty of Medical Sciences, University of Jos, Jos, Plateau State, Nigeria. ${ }^{7}$ Hassan II Univesity Ain chock, Casablanca, Morocco. ${ }^{8}$ Department of Neurology, The University of Chicago, Chicago, IL 60637, USA.

Received: 20 November 2019 Accepted: 18 June 2020 Published online: 03 July 2020

\section{References}

1. Fenga C. Occupational exposure and risk of breast cancer. Biomed Rep. 2016:4:282-92.

2. DeSantis CE, Bray F, Ferlay J, Lortet-Tieulent J, Anderson BO, Jemal A. International variation in female breast Cancer incidence and mortality rates. Cancer Epidemiol Biomark Prev. 2015;24:1495-506.

3. Veeraraghavan J, Ma J, Hu Y, Wang X-S. Recurrent and pathological gene fusions in breast cancer: current advances in genomic discovery and clinical implications. Breast Cancer Res Treat. 2016;158:219-32.

4. Jara L, Morales S, de Mayo T, Gonzalez-Hormazabal P, Carrasco V, Godoy R. Mutations in BRCA1, BRCA2 and other breast and ovarian cancer susceptibility genes in central and south American populations. Biol Res. 2017;50:35.

5. Bunz F, Hwang PM, Torrance C, Waldman T, Zhang Y, Dillehay L, et al. Disruption of p53 in human cancer cells alters the responses to therapeutic agents. J Clin Invest. 1999;104:263-9.

6. Lehmann-Che J, Turpin E, Bertheau P, Espié M, de Thé H. Exquisite sensitivity of TP53 mutant breast cancers to dose-dense chemotherapy. Med Sci (Paris). 2007;23:1021-3.

7. Sharma S, Sambyal V, Guleria K, Manjari M, Sudan M, Uppal MS, et al. TP53 polymorphisms in sporadic North Indian breast cancer patients. Asian Pac J Cancer Prev. 2014;15:6871-9.

8. Lamb P, Crawford L. Characterization of the human p53 gene. Mol Cell Biol. 1986;6:1379-85.

9. Sommer SS, Cunningham J, McGovern RM, Saitoh S, Schroeder JJ, Wold LE, et al. Pattern of p53 gene mutations in breast cancers of women of the midwestern United States. J Natl Cancer Inst. 1992;84:246-52.

10. Blaszyk H, Hartmann A, Tamura Y, Saitoh S, Cunningham JM, McGovern RM, et al. Molecular epidemiology of breast cancers innorthern and southern Japan: the frequency, clustering, and patterns of p53 gene mutations differ among these two low-risk populations. Oncogene. 1996;13:2159-66.

11. Isobe M, Emanuel BS, Givol D, Oren M, Croce CM. Localization of gene for human p53 tumour antigen to band 17p13. Nature. 1986;320:84-5.

12. Zhang Z, Wang M, Wu D, Wang M, Tong N, Tian Y, et al. P53 codon 72 polymorphism contributes to breast cancer risk: a meta-analysis based on 39 case-control studies. Breast Cancer Res Treat. 2010;120:509-17.

13. Gemignani F, Moreno V, Landi S, Moullan N, Chabrier A, Gutiérrez-Enríquez $\mathrm{S}$, et al. A TP53 polymorphism is associated with increased risk of colorectal cancer and with reduced levels of TP53 mRNA. Oncogene. 2004;23:1954-6.

14. Lazar V, Hazard F, Bertin F, Janin N, Bellet D, Bressac B. Simple sequencerepeat polymorphism within the p53 gene. Oncogene. 1993;8:1703-5.
15. Hillebrandt S, Streffer C, Demidchik EP, Biko J, Reiners C. Polymorphisms in the p53 gene in thyroid tumours and blood samples of children from areas in Belarus. Mutat Res. 1997;381:201-7.

16. Wang-Gohrke S, Becher H, Kreienberg R, Runnebaum IB, Chang-Claude J. Intron 316 bp duplication polymorphism of p53 is associated with an increased risk for breast cancer by the age of 50 years. Pharmacogenetics. 2002;12:269-72.

17. Costa S, Pinto D, Pereira D, Rodrigues H, Cameselle-Teijeiro J, Medeiros R, et al. Importance of TP53 codon 72 and intron 3 duplication 16bp polymorphisms in prediction of susceptibility on breast cancer. BMC Cancer. 2008;8:32.

18. Akkiprik M, Sonmez O, Gulluoglu BM, Caglar HB, Kaya H, Demirkalem P, et al. Analysis of p53 gene polymorphisms and protein over-expression in patients with breast cancer. Pathol Oncol Res. 2009;15:359-68.

19. Marouf C, Tazzite A, Diakité B, Jouhadi H, Benider A, Nadifi S. Association of TP53 PIN3 polymorphism with breast cancer in Moroccan population. Tumor Biol. 2014;35:12403-8.

20. Morten BC, Chiu S, Oldmeadow C, Lubinski J, Scott RJ, Avery-Kiejda KA. The intron 316 bp duplication polymorphism of p53 (rs17878362) is not associated with increased risk of developing triple-negative breast cancer. Breast Cancer Res Treat. 2019;173:727-33.

21. Hu Z, Li X, Yuan R, Ring BZ, Su L. Three common TP53 polymorphisms in susceptibility to breast cancer, evidence from meta-analysis. Breast Cancer Res Treat. 2010;120:705-14.

22. Sagne C, Marcel V, Amadou A, Hainaut P, Olivier M, Hall J. A meta-analysis of cancer risk associated with the TP53 intron 3 duplication polymorphism (rs17878362): geographic and tumor-specific effects. Cell Death Dis. 2013:4:e492.

23. Gohari-Lasaki S, Gharesouran J, Ghojazadeh M, Montazeri V, Mohaddes Ardebili SM. Lack of influence of TP53 Arg72Pro and 16bp duplication polymorphisms on risk of breast cancer in Iran. Asian Pac J Cancer Prev. 2015;16:2971-4.

24. Hashemi M, Amininia S, Ebrahimi M, Simforoosh N, Basiri A, Ziaee SAM, et al. Association between polymorphisms in TP53 and MDM2 genes and susceptibility to prostate cancer. Oncol Lett. 2017;13:2483-9.

25. Higgins JPT, Thompson SG. Quantifying heterogeneity in a meta-analysis. Stat Med. 2002;21:1539-58.

26. Buyru N, Altinisik J, Demokan S, Dalay N. p53 genotypes and haplotypes associated with risk of breast cancer. Cancer Detect Prev. 2007;31:207-13.

27. Cherdyntseva NV, Denisov EV, Litviakov NV, Maksimov VN, Malinovskaya EA, Babyshkina NN, et al. Crosstalk between the FGFR2 and TP53 genes in breast cancer: data from an association study and epistatic interaction analysis. DNA Cell Biol. 2012;31:306-16.

28. De Vecchi G, Verderio P, Pizzamiglio S, Manoukian S, Bernard L, Pensotti V, et al. The p53 Arg72Pro and Ins16bp polymorphisms and their haplotypes are not associated with breast cancer risk in BRCA-mutation negative familial cases. Cancer Detect Prev. 2008;32:140-3.

29. Gaudet MM, Gammon MD, Bensen JT, Sagiv SK, Shantakumar S, Teitelbaum SL, et al. Genetic variation of TP53, polycyclic aromatic hydrocarbon-related exposures, and breast cancer risk among women on Long Island, New York. Breast Cancer Res Treat. 2008;108:93-9.

30. Guleria K, Sharma S, Manjari M, Uppal MS, Singh NR, Sambyal V. P.R72P PIN3 Ins16bp polymorphisms of TP53 and CCR5?32 in north Indian breast cancer patients. Asian Pac J Cancer Prev. 2012;13:3305-11.

31. Hao W, Xu X, Shi H, Zhang C, Chen X. No association of TP53 codon 72 and intron 3 16-bp duplication polymorphisms with breast cancer risk in Chinese Han women: new evidence from a population-based case-control investigation. Eur J Med Res. 2018;23:47.

32. Hrstka R, Beranek M, Klocova K, Nenutil R, Vojtesek B. Intronic polymorphisms in TP53 indicate lymph node metastasis in breast cancer. Oncol Rep. 2009;22:1205-11.

33. Pouladi N, Kouhsari SM, Feizi MH, Dehghan R, Azarfam P, Farajzadeh D. Lack of association of intron 316 bp polymorphism of TP53 with breast cancer among Iranian-Azeri patients. Asian Pac J Cancer Prev. 2014;15:2631-4.

34. Suspitsin EN, Buslov KG, Grigoriev MY, Ishutkina JG, Ulibina JM, Gorodinskaya VM, et al. Evidence against involvement of p53 polymorphism in breast cancer predisposition. Int J Cancer. 2003;103:431-3.

35. Trifa F, Karray-Chouayekh S, Mabrouk I, Baccouche S, Khabir A, SellamiBoudawara T, et al. Haplotype analysis of p53 polymorphisms: Arg72Pro, Ins16bp and G13964C in Tunisian patients with familial or sporadic breast cancer. Cancer Epidemiol. 2010;34:184-8. 
36. Vymetalkova V, Soucek P, Kunicka T, Jiraskova K, Brynychova V, Pardini B, et al. Genotype and Haplotype Analyses of TP53 Gene in Breast Cancer Patients: Association with Risk and Clinical Outcomes. PLoS One. 2015; 30(10):e0134463.

37. Weston A, Pan CF, Ksieski HB, Wallenstein S, Berkowitz GS, Tartter PI, et al. p53 haplotype determination inbreast cancer. Cancer Epidemiol Biomark Prev. 1997;6:105-12.

38. Bisof V, Salihović MP, Narancić NS, Skarić-Jurić T, Jakić-Razumović J, Janićijević B, Turek S, Rudan P. TP53 gene polymorphisms and breast cancer in Croatian women: a pilot study. Eur J Gynaecol Oncol. 2010;31(5):539-44.

39. Alawadi S, Ghabreau L, Alsaleh M, Abdulaziz Z, Rafeek M, Akil N, et al. P53 gene polymorphisms and breast cancer risk in Arab women. Med Oncol. 2011;28:709-15.

40. Faghani M, Ghasemi FM, Nikhbakht M, Salehi M. TP53 PIN3 polymorphism associated with breast cancer risk in Iranian women. Indian J Cancer. 2011; 48:298-302.

41. Wu D, Zhang Z, Chu H, Xu M, Xue Y, Zhu H, et al. Intron 3 sixteen base pairs duplication polymorphism of p53 contributes to breast cancer susceptibility: evidence from meta-analysis. PLoS One. 2013;8:e61662.

42. Jakubowska A, Gronwald J, Menkiszak J, Górski B, Huzarski T, Byrski T, et al. BRCA1-associated breast and ovarian cancer risks in Poland: no association with commonly studied polymorphisms. Breast Cancer Res Treat. 2010;119:201-11.

43. Courtois S, Verhaegh G, North S, Luciani M-G, Lassus P, Hibner U, et al. DeltaN-p53, a natural isoform of p53 lacking the first transactivation domain, counteracts growth suppression by wild-type p53. Oncogene. 2002;21:6722-8.

44. Ghosh A, Stewart D, Matlashewski G. Regulation of human p53 activity and cell localization by alternative splicing. Mol Cell Biol. 2004;24:7987-97.

45. Pouladi N, Abdolahi S, Farajzadeh D, Hosseinpour Feizi MA. Haplotype and linkage disequilibrium of TP53-WRAP53 locus in Iranian-Azeri women with breast cancer. PLoS One. 2019;14:e0220727.

46. Wu X, Zhao H, Amos Cl, Shete S, Makan N, Hong WK, et al. p53 genotypes and haplotypes associated with lung cancer susceptibility and ethnicity. J Natl Cancer Inst. 2002;94:681-90.

\section{Publisher's Note}

Springer Nature remains neutral with regard to jurisdictional claims in published maps and institutional affiliations.

Ready to submit your research? Choose BMC and benefit from:

- fast, convenient online submission

- thorough peer review by experienced researchers in your field

- rapid publication on acceptance

- support for research data, including large and complex data types

- gold Open Access which fosters wider collaboration and increased citations

- maximum visibility for your research: over $100 \mathrm{M}$ website views per year

At $\mathrm{BMC}$, research is always in progress.

Learn more biomedcentral.com/submissions 